http://journal.uinsgd.ac.id/index.php/biodjati

\title{
TREATMENT OF PLGA NANOPARTICLES OINTMENT-ETHANOL EXTRACT OF Archidendron pauciflorum IN THE WOUND HEALING IN DIABETIC MICE
}

\author{
Desak Made Malini' ${ }^{1 *}$, Yasmi Purnamasari Kuntana², Madihah³, Wildanul Furqon ${ }^{4}$, \\ Wawan Hermawan 5
}

Received : August 08, 2020

Accepted : September 29, 2020

DOI: 10.15575/biodjati.v5i2.9256

1,2,3,4,5 Departement of Biology, Faculty of Mathematics and Natural Sciences, Universitas Padjadjaran. Jl. Bandung -Sumedang Km 21, Jatinangor, Sumedang 45363, West Java, Indonesia. Tel./Fax. +62-22-7796412

e-mail:

*1desak.made@unpad.ac.id

${ }^{2}$ y.purnamasari@unpad.ac.id

${ }^{3}$ madihah@unpad.ac.id

${ }^{4}$ wildannurforqon@gmail.com

${ }^{5}$ wawan.hermawan@unpad.ac.id

*Corresponding author

\begin{abstract}
Diabetic wounds lead to severe tissue damage and are difficult to cure. Jengkol (Archidendron pauciflorum) is a plant commonly used by local Indonesian communities to treat diabetic wounds. The efficiency of herbal medicine still has a deficiency of its ability to reach the target organs, therefore nanotechnology is applied in the hope that all drug concentrations can reach the target organs successfully. This study aimed to evaluate the effectiveness of PLGA nanoparticle ointment-ethanol extract jengkol fruit peel (EEJFP) to accelerate the wound healing process in the skin of streptozotocin-induced diabetic mice. The research method used was experimental with a completely randomized design using six treatments and four replications. Diabetes was induced by intraperitoneal injection of streptozotocin $180 \mathrm{mg} /$ $\mathrm{kg} \mathrm{BW}$. Mice with a blood glucose level of $\geq 150 \mathrm{mg} / \mathrm{dL}$ were used for diabetic mice models. The incision wound created at the dorsolateral region of shaven skin at $\pm 1 \mathrm{~cm} 2$ using sterile scissors. The treatments given were vaseline for Control Negative $(C N)$ and Control Positive $(C P)$, Betadine ointment (PB), 10\% EEJFP ointment (P1), 5\% PLGA nanoparticle ointment-EEJFP (P2), and 2.5\% PLGA nanoparticle ointment-EEJFP (P3). The results showed that the administration of PLGA nanoparticles ointment-EEJFP with a concentration of 5\% PLGA nanoparticle ointment-EEJFP (P2) resulted in the shortest wound length on day 3, 7 and 14; narrower granulation tissue; a larger number of blood capillaries; and denser collagen fibers $(\alpha<0.05)$ compared to $C P$ and $P B$ treatments. The administration of PLGA nanoparticle ointment-EEJFP with a concentration of $5 \%$ was the most effective concentration in accelerating wound healing in the skin of diabetic mice.
\end{abstract}

Keywords: diabetic wounds, jengkol, nanoparticles, ointment, PLGA

\section{Citation}

Malini, D. M., Kuntana, Y. P., Madihah, Furqon, W. \& Hermawan, W. (2020). Treatment of PLGA Nanoparticles Ointment-Ethanol Extract of Archidendron pauciflorum in the Wound Healing in Diabetic Mice. Jurnal Biodjati, 5(2), 214-222. 


\section{JURNAL BIDDJATI}

http://journal.uinsgd.ac.id/index.php/biodjati

\section{INTRODUCTION}

Diabetes wound (diabetic ulcure) is a further complication of the condition experienced by a person with diabetes mellitus, characterized by an open wound on the epidermal layer to the dermis layer with blackish-red color, and foul-smelling. This occurs because of the clogged blood vessel in the palm or soles (Sudayo et al., 2009). The widely used remedy for diabetic wounds is povidone iodine (Betadine ${ }^{\mathbb{R}}$ ). This drug can kill bacteria (bactericides) and fungi (fungicides) at a concentration of $0.1-1 \%$ but has several side effects including irritating the wound during the healing process (Rahmawati, 2014). Based on this fact, it is necessary to cure a wound of diabetes without any side effects that cause more severe injury and safe.

One of the plants that have been used traditionally in several regions in Indonesia as a cure for diabetes mellitus is jengkol fruit peel. According to Malini et al. (2017), the people of Karangwangi Village use have been using jengkol fruit peel to treat diabetes wounds because they are easy to obtain and have no side effects. Jengkol fruit peel contains flavonoids, quinones, tannins, saponins, polyphenols, glycosides, and steroids. These compounds play a role in wound healing because they are astringent, have antioxidant and antimicrobial properties, stimulates re-epithelialization and neovascularization, as well as triggers collagen growth (Francis et al., 2002).

The efficiency of herbal medicines derived from nature has a disadvantage, such as its ability to reach the target organ as only a small concentration can reach it, while most of it is distributed to the other body parts. Nanoparticles are a technology that aims to make dosage forms in the range of $10 \mathrm{~nm}$ $1000 \mathrm{~nm}$ (Aloys et al., 2016). The smallest capillaries in the body have a diameter of 5-6 $\mathrm{mm}$, therefore, natural medicines in nano size can be distributed to all blood vessels in the body (Mathur \& Govind, 2013). Nano preparations must be encapsulated by polymers that are biocompatible and biodegradable. Encapsulation polymers commonly used are PLGA (polylactic glycolic acid) alginate, chitosan, gelatin, and ethylcellulose. PLGA is the most commonly used polymer in the encapsulation of nanoparticles and is an effective carrier in drug delivery to target organs. PLGA polymers have been approved by the Food and Drug Administration (FDA) for human therapy (Danhier et al., 2012). According to Chereddy et al. (2014), PLGA nanoparticles are nano compatible polymer-carriers and act as promoters of wound healing, stimulating re-epithelialization, neovascularization, and collagen fiber density.

Research on the effectiveness of PLGA nanoparticle ointment-ethanol extract of jengkol fruit peel to treat diabetic wounds has not been widely reported. Therefore this study aimed to test the effectiveness of PLGA nanoparticle ointment-ethanol extract of jengkol fruit peel on the process of wound closure and repair the histological damage of the skin in mice (M. musculus) diabetes.

\section{MATERIALS AND METHODS}

The research was conducted at the Laboratory of Structural and Animal Physiology, Universitas Padjadjaran from May to July 2019.

\section{Preparation of Ethanol Extract of Jengkol Fruit Peel}

Jengkol fruit peel was collected from Karangwangi village, Cianjur District, West Java Province, Indonesia. The samples were identified in the Taxonomy laboratory in the Biology Department, Faculty of Mathematics 


\section{JURNAL BIDDJATI}

http://journal.uinsgd.ac.id/index.php/biodjati

and Sciences, Universitas Padjadjaran. The samples were air-dried to a constant weight and blend to a coarse powder. The dried powder was soaked and macerated on ethanol 70\% (ratio 1:2) for 72 hours and every 24 hours the macerate was collected. The macerate was then evaporated using a rotary evaporator at a temperature of $40-50^{\circ} \mathrm{C}$, and freeze-dried to obtain a paste extract (Khan et al., 2012).

\section{Preparation of PLGA Nanoparticles Etha- nol Extract of Jengkol Fruit Peel}

The manufacture of PLGA nanoparticles was carried out by nanoprecipitation techniques based on Fessi et al. (1989). Fifty milligrams of PLGA and $10 \mathrm{mg}$ of jengkol fruit peel ethanol extract were weighed and dissolved in $3 \mathrm{~mL}$ acetone, then added dropwise $(0.5 \mathrm{~mL} / \mathrm{min})$ to a solution containing 20 $\mathrm{mL}$ stabilizer ( $1 \%$ polyoxyethylene-polyoxypropylene in aquadest). The mixed solution was stirred at $400 \mathrm{rpm}$ using a stirrer at room temperature until the organic solvent evaporates. Afterward, centrifugation was carried out at $25,000 \mathrm{rpm}$ and $4^{\circ} \mathrm{C}$ for 30 minutes. The pellet was then suspended again in Milli-Q water and washed three times. The suspension contained solid particles roasted at a temperature of $30^{\circ} \mathrm{C}$ for 24 hours, after which they were grounded until smooth to form a powder.

\section{Preparation of PLGA Nanoparticles Oint- ment-Ethanol Extract of Jengkol Fruit Peel and Ointment of Ethanol Extract of Jengkol Fruit Peel}

The PLGA-ethanol extract ointment for jengkol fruit peel was made for 15 grams in weight with two concentrations of $5 \%$ and $2.5 \%$, while the ethanol extract ointment for jengkol fruit peel was made for 15 grams in weight with a concentration of $10 \%$. Each concentration of ointment was homogenized with vaseline using a mortar that was heated to a temperature of $75^{\circ} \mathrm{C}$ (Winarsih et al., 2012). Ointments were stored in film bottles and labeled.

\section{Experimental Design}

Twenty-four male Swiss-Webster mice (8-12 weeks old, 30-40 g of weight) were obtained from the Faculty of Animal Husbandry Universitas Padjadjaran. They were housed in standard environmental conditions and fed with piglet standard diets (CP-551, PT. Charoen Pokphand) and water ad libitum. The animals were acclimatized for seven days before the experiment. The experiment used a completely randomized design with six treatments and four replications.

\section{Induction of Diabetes}

The animals fasted for 4-6 hours, and their baseline fasting blood glucose level was measured using a glucometer, by collecting blood via tail cut before induction of diabetes. Diabetes was induced by intraperitoneal injection of a freshly prepared solution of STZ (Nacalai Tesque, Inc.) with a dose of $180 \mathrm{mg} / \mathrm{kg}$ BW in $10 \mathrm{mM}$ citrate buffer solution $\mathrm{pH} 4.5$ of five groups, while the negative control mice were injected with the vehicle. The mice were provided with $10 \%$ of sucrose solution for three constitutive days to prevent hypoglycemia after STZ induction. Four days after administration of STZ, the mice fasted and the blood was collected via tail cut for measuring their fasting glucose levels. The animals which have glucose level more than $150 \mathrm{mg} / \mathrm{dL}$ were used for further experiment and categorized as diabetic mice (Wu \& Huan, 2008; Furman, 2015).

\section{The Procedure of the Wound Creation and Treatment with the Ointment}

The mice were anesthetized with inhaled ether, and then the hair on the right 


\section{JURNAL BIDDJATI}

http://journal.uinsgd.ac.id/index.php/biodjati

side of the cutting area was shaved before the creation of the wound. Incision wounds were created on all mice by cutting the dorsolateral surface of skin $\pm 1.5 \mathrm{~cm}$ from the shaven area using sterile scissors (full-thickness type extending up to the adipose tissue). The ointment treatment was smeared twice a day in the morning and afternoon for 14 days consecutively. The animals were allowed to consume food and water ad libitum (Chen et al., 2005; Winarsih et al., 2012).

\section{Histological Preparation and Examination}

On the 15th days, after an overnight fast, the animals were weighed and sacrificed by cervical dislocation, wounds were harvested and fixed in $10 \%$ of neutral buffered formalin. The tissue was dried using a serial of N-butanol-xylene solution, inserted in paraffin, sectioned at 5-7 $\mu \mathrm{m}$ thickness, mounted on glass slides, stained with hematoxylin and eosin as well as Trchrome Heidenhains Azan. The histological examination included the percentage of reepithelization, formation of the granulation tissue, number of blood capillaries, and density of collagen in five areas per slide.

\section{Data Analysis}

The results were expressed as mean values \pm standard deviation (S.D). Statistical significance for the granulation tissue area, and the number of blood capillaries was analyzed using one-way ANOVA followed by Duncan's multiple range test. Whereas the density of collagen was analyzed by the Kruskal-Wallis test. P values less than 0.05 were considered significant.

\section{RESULTS AND DISCUSSION}

\section{The Effect of PLGA Nanoparticle Ointment -EEJFP on Granulation Tissue}

Histological observations on granula- tion tissue showed that negative control treatments had the narrowest granulation tissue, whereas positive control treatments had the most extensive granulation tissue, compared to other treatments (Table 1). It happened because the vaseline does not contain active ingredients that can accelerate the wound healing process, causing the granulation tissue constriction to occur longer (Yanhendri \& Yenny, 2012). The treatment of Ethanol extract of Jengkol Fruit Peel (EEJFP) ointment and PLGA nanoparticle ointment-EEJFP has granulation tissue that was narrower than the comparative treatment using betadine and positive control treatment (Figure 1). This is due to the fruit peel of jengkol containing phytochemical compounds such as saponins and tannins.

Tannins contained in jengkol fruit peel are thought to act as an antibacterial by denaturing cell proteins. The hydrogen bonds formed between tannins and bacterial proteins cause the structure of the protein to become damaged. The hydrogen bond affects the permeability of the cell wall and cytoplasmic membrane, both of which are composed of proteins. The permeability of the disrupted cell wall and cell membrane can cause an imbalance of macromolecules and ions in the cell resulting in cell microbial lysis (Sari \& Sari, 2011).

Flavonoids are powerful antioxidants that can control free radicals, protect the body against reactive oxygen species (ROS), enhance endogenous antioxidant functions, and increase antioxidant enzymes in granulation tissue (Keller et al., 2006). Flavonoids play a role in inhibiting inflammatory mediators such as interleukin-1 (IL-1) and tumor necrosis factor (TNF) produced by macrophages and cytokine receptors that are generally seen in pain suppression and tissue damage (Saroja et al., 2012). 
Jurnal Biodjati 5(2):214-222, November 2020

\section{JURNAL BIDDJATI}

http://journal.uinsgd.ac.id/index.php/biodjati

Table 1. The Average Area of Granulation Tissue, The Number of Blood Capillaries, and Collagen Fiber Density Scores in Diabetic Mice Skin Lesions

\begin{tabular}{|c|c|c|c|c|}
\hline & Treatment & $\begin{array}{c}\text { Average Area of } \\
\text { Granulation Tissues } \\
\pm \mathrm{SD}\left(\mu \mathrm{m}^{2}\right) \\
\end{array}$ & $\begin{array}{c}\text { Average The } \\
\text { Number of Blood } \\
\text { Capillaries } \pm \text { SD }\end{array}$ & $\begin{array}{c}\text { Average Collagen } \\
\text { Density Score } \pm \text { SD }\end{array}$ \\
\hline $\begin{array}{l}\text { Negative } \\
\text { control }\end{array}$ & $\begin{array}{l}\text { Without STZ + Vaseline } \\
\text { Induction }\end{array}$ & $18.50 \pm 1.29^{\mathrm{a}}$ & $4.00 \pm 0.00^{\mathrm{a}}$ & $2054.83 \pm 164.31^{\mathrm{a}}$ \\
\hline $\begin{array}{l}\text { Positive } \\
\text { control }\end{array}$ & Induced STZ + Vaseline & $4.50 \pm 1.29^{d}$ & $1.62 \pm 0.47^{\mathrm{c}}$ & $5123.61 \pm 242.47^{\mathrm{e}}$ \\
\hline Comparative & $\begin{array}{l}\text { Induced STZ + Beta- } \\
\text { dine Ointment }\end{array}$ & $11.50 \pm 1.29^{\mathrm{c}}$ & $2.00 \pm 0.40^{c}$ & $3679.48 \pm 58.62^{\mathrm{d}}$ \\
\hline Treatment 1 & $\begin{array}{l}\text { Induced STZ }+10 \% \text { of } \\
\text { EEKBJ Ointment }\end{array}$ & $14.25 \pm 0.95^{\mathrm{b}}$ & $3.50 \pm 0.40^{\mathrm{b}}$ & $2885.91 \pm 95.30^{c}$ \\
\hline Treatment 2 & $\begin{array}{l}\text { Induced STZ + } 5 \% \text { of } \\
\text { PLGA-EEKBJ Nano- } \\
\text { particles Ointment }\end{array}$ & $17.25 \pm 2.06^{\mathrm{a}}$ & $4.00 \pm 0.00^{\mathrm{a}}$ & $2058.84 \pm 50.30^{\mathrm{a}}$ \\
\hline Treatment 3 & $\begin{array}{l}\text { Induced STZ + 2,5\% of } \\
\text { PLGA-EEKBJ Nano- } \\
\text { particles Ointment }\end{array}$ & $14.50 \pm 1.29^{\mathrm{b}}$ & $3.68 \pm 0.23^{b}$ & $2655.29 \pm 64.09^{\mathrm{b}}$ \\
\hline
\end{tabular}

Note: The numbers followed by the same letters show no significant difference based on Mann Whitney $U$ test for granulation tissue test at the $95 \%$ significance leveland the number of blood capillaries. Whereas the density of collagen was analyzed by the Kruskal-Wallis test. P values less than 0.05 were considered significant.
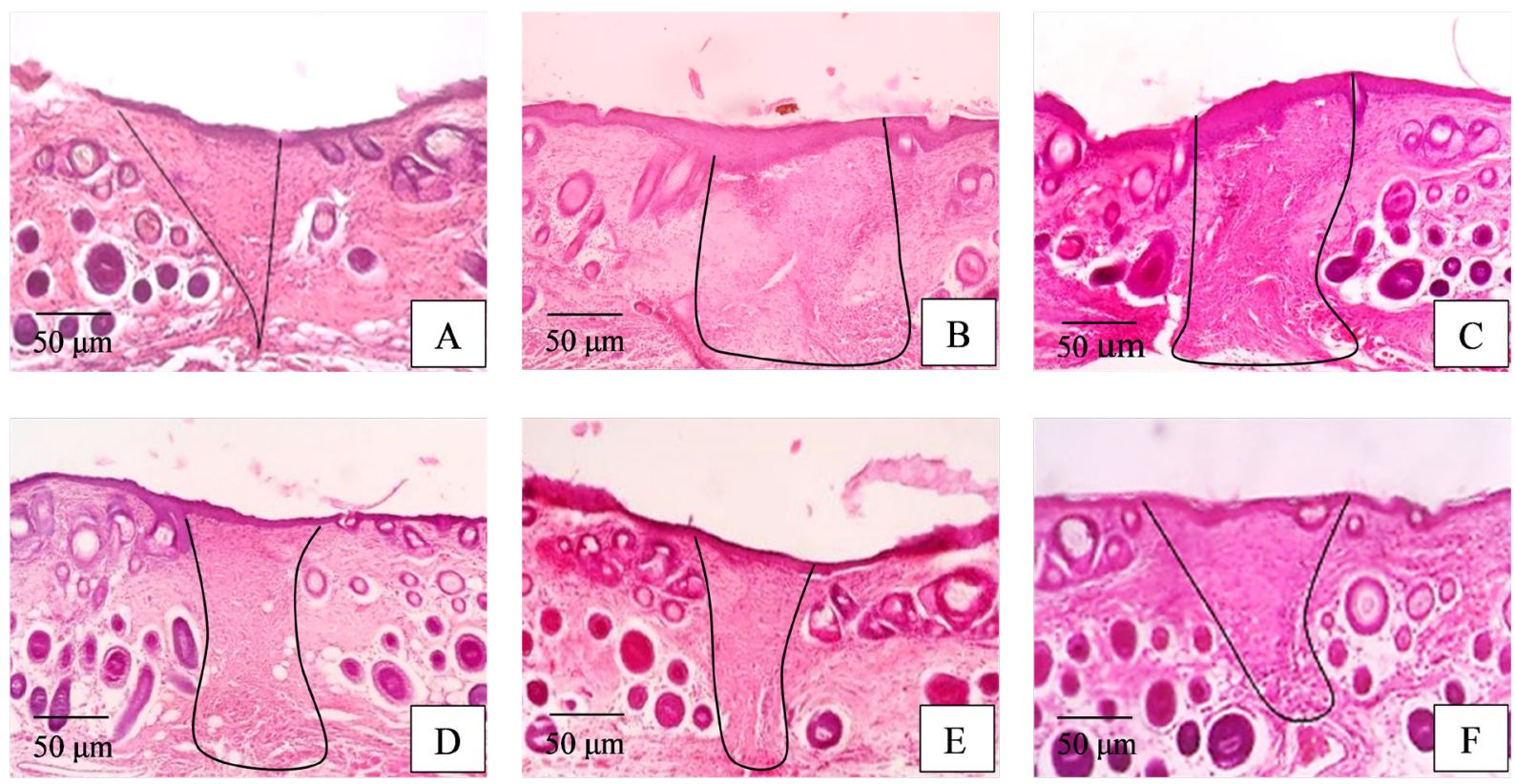

Figure 1. Photomicrograph of the cross section of mice skin from each treatment groups after treatments for 14 days. Hematoxylin Eosin stain. M.100×. (A). Negative control (non-diabetic mice +vaseline); (B) Positive control (diabetic mice +vaseline); (C) Comparative (diabetic mice +Betadine ointment); (D) Treatment 1 (diabetic mice $+10 \%$ EEJFP ointment); (E) Treatment 2 (diabetic mice $+5 \%$ PLGA nanoparticles ointment- EEJFP); (F) Treatment 3 (diabetic mice + 2,5\% PLGA nanoparticles ointment- EEJFP). 


\section{JURNAL BIDDJATI}

http://journal.uinsgd.ac.id/index.php/biodjati

\section{The Effect of PLGA Nanoparticle Oint- ment-EEJFP on The Number of Blood Capillaries}

The results of Duncan's multiple range test analysis $(\alpha<0.05)$ showed that the positive control treatment was significantly different from the negative control. The positive control treatment had the lowest number of blood capillaries, whereas the negative control treatment had the highest number of blood capillaries compared to other treatments (Table 1). In the positive control, mice experienced hyperglycemia which caused a reduced supply of nutrients and oxygen in the injured area for the formation of new blood vessels (neovascularization).

The treatment of PLGA nanoparticle with a concentration of $5 \%$ had the narrowest granulation tissue area as well as negative control treatments that were not induced by diabetes (Figure 1). This is caused by phytochemical compounds found in the jengkol fruit peel which play a role in the formation of new blood vessels. As one of the compounds, flavonoids can help to repair damaged blood vessels by inhibiting the action of ROS, where one free electron contained in the flavonoid binds to one free electron contained in the ROS. Therefore there is no tissue damage caused by ROS and the neovascularization process takes place quickly (Keller et al., 2006).

\section{The Effect of PLGA Nanoparticle Ointment -EEJFP on Collagen Density}

The results of the Mann Whitney U test analysis $(\alpha<0.05)$ showed that the positive control treatment was significantly different from the negative control (Table 1). This is due to the condition of high glucose levels in the blood that can inhibit the wound healing process so that the process of formation of collagen fibers takes place slowly. According to Robert et al. (2006), the low collagen density in diabetic wounds is due to an abnormal process in the wound healing process, namely the poor circulation of nutrients, oxygen, hormones, and growth factors due to the presence of hyperglycemia.

The treatments of jengkol fruit peel ointment both in extract form and in the form of nanoformulation were significantly different from the comparison treatments. This shows that herbal medicines derived from nature were more effective than antiseptic (povidone-iodine). The treatment of jengkol fruit peel in the form of extracts and nanoformulations had a high value of collagen fiber density compared to the comparative treatments (Figure 2), this is because jengkol fruit peel contains several phytochemical compounds that play a role in the process of formation of collagen fibers.

One of the antioxidants found in the body is ascorbic acid, which is a material needed in collagen synthesis (Hartanto, 2013). One of the phytochemicals contained in jengkol fruit peel is flavonoids. It contains antiscorbutic which can protect ascorbic acid from ROS (Nisa et al., 2013). Flavonoids protect ascorbic acid from ROS by inhibiting cyclooxygenase and lipoxygenase, so there is a limitation on the number of inflammatory cells that migrate to wound tissue (Napangala et al., 2012). This will cause an inflammatory reaction and the time of exposure to wound tissue to ROS to be shorter so that the levels of ascorbic acid in the body can be maintained and the process of collagen synthesis can take place quickly.

Saponins contained in jengkol fruit peel play a role in stimulating the synthesis of fibronectin by fibroblasts (Gurtner, 2007), by increasing the ability of TGF- $\beta$ receptors contained in fibroblasts to bind to TGF- $\beta$ which is a growth factor needed by fibroblasts in citing 
Jurnal Biodjati 5(2):214-222, November 2020

\section{JURNAL BIDDJATI}

http://journal.uinsgd.ac.id/index.php/biodjati

collagen (Agarwal et al., 2009). This causes the migration of fibroblasts by fibronectin will be faster so that there will mire collagen synthesized by fibroblasts.

The collagen density of the treatment of PLGA Nanoparticle Ointment-EEJFP in a concentration of $5 \%$ was significantly different from the treatment of EEJFP a concentration of $10 \%$ but was not significantly different from the negative control treatment (Table 1). This shows that nanoparticle carriers can reduce the use of ointment concentrations ( $1 / 2$ of the usual concentration). It is supported by Oktaviana et al. (2016), which stated that the use of PLGA nanoparticles can increase the bioavailability profile of herbal medicines and encapsulate extracts to minimize the degradation of extracts and easily absorb them more quickly to increase the effectiveness of diabetes wound therapy. Nano- technology provides a safe drug delivery system because all concentrations of therapeutic agents are delivered directly into cells, tissues, and organs in certain periods (Sahoo \& Labhasetwar, 2003). In general, nanoparticle drugs have several advantages, including increasing solubility and bioavailability, pharmacological activity, and distribution of macrophages in tissues, preventing physical and chemical degradation (Raffa et al., 2010).

\section{ACKNOWLEDGEMENTS}

The research was supported by the Directorate of Research, Technology and Higher Education of the Republic of Indonesia. In this opportunity, we gratefully acknowledge the financial support of the PUPT with contract number No. 3916/UN6. $\mathrm{RKT} / \mathrm{KP} / 2015$ budget year 2018.
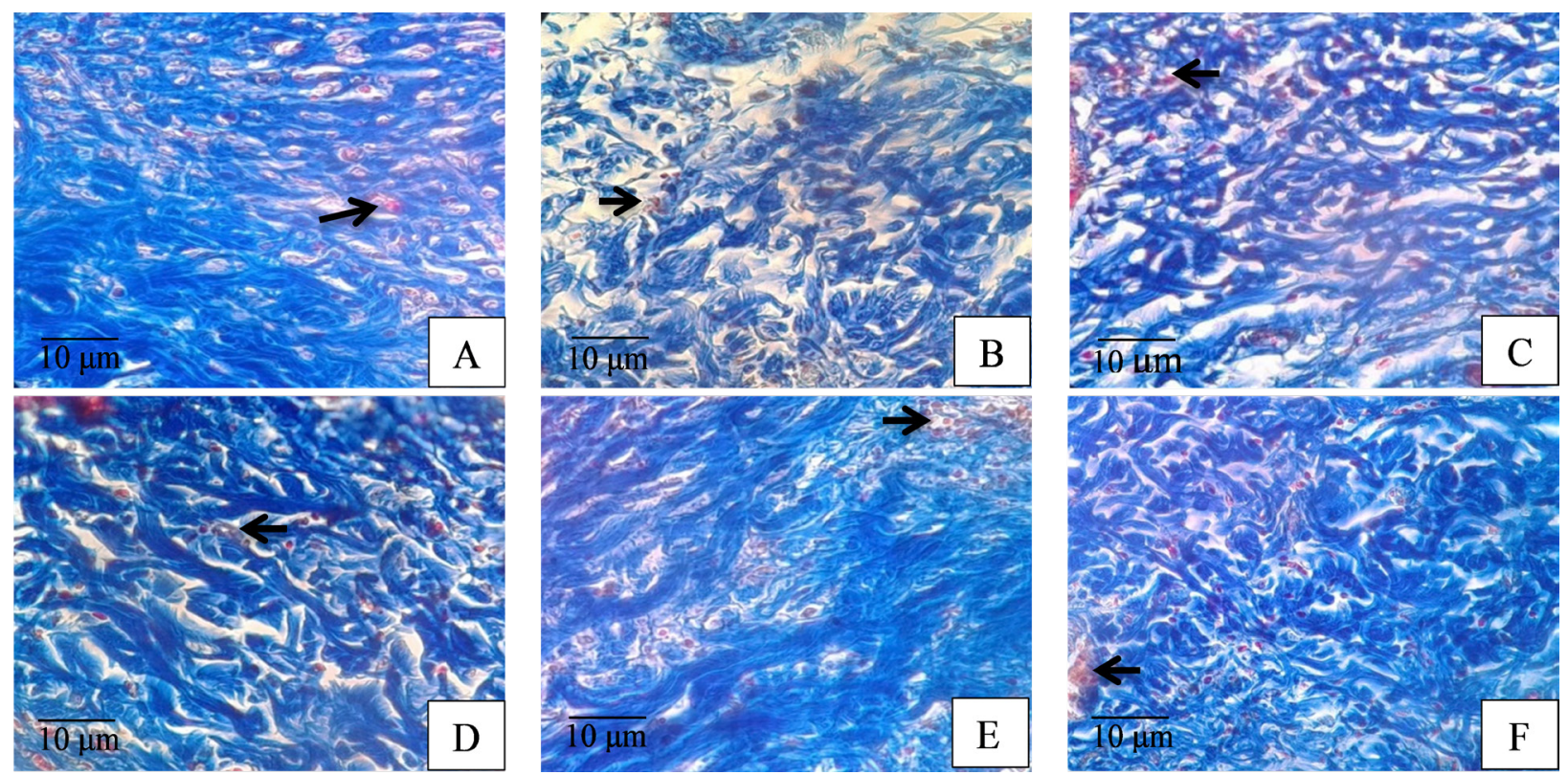

Figure 2. Photomicrograph of the cross-section of mice skin from each treatment group after treatments for 14 days. Heidenhain's Trichrome Azan stain. M.100×. Note Blood capillary (arrow); collagen in blue color. (A). Negative control (non-diabetic mice +vaseline); (B) Positive control (diabetic mice +vaseline); (C) Comparative (diabetic mice +Betadine ointment); (D) Treatment 1 (diabetic mice $+10 \%$ EEJFP ointment); (E) Treatment 2 (diabetic mice $+5 \%$ PLGA nanoparticles ointment- EEJFP); (F) Treatment 3 (diabetic mice + $2,5 \%$ PLGA nanoparticles ointment- EEJFP).. 


\section{JURNAL BIDDJATI}

http://journal.uinsgd.ac.id/index.php/biodjati

\section{REFERENCES}

Agarwal, P. K., Singh, A., Gaurav, K., Goel, S., Khanna, H. D. \& Goel, R. K. (2009). Evaluation of Wound Healing Activity of Extracts of Plantain Banana ( $M$. sapientum var. paradisiaca) in rats. Indian Journal of Experimental Biology, 47(1), 322-40.

Aloys, H., Korma, S. A., Alice, T. M., Chantal, N., Ali, A. H., Abed, S. M. \& Lidephonse, H. (2016). Microencapsulation by Complex Coacervation: Methods, Techniques, Benefits , and Applications - A Review. American Journal of Food Science and Nutrition Research, 3(6), 188-192.

Chen, J., Kamper, M., Heck, T., Nakagawa, K., Humpert, P. M., Bai, L., Wu, G., Zhang, Y., Luther, T., Andrassay, M., Shicekofer, S., Hamann, A., Morcos, M., Chain, B., Ster, M. D., Naworth, P. $\&$ Bierhaus, A. (2005). Tissue Factor as a Link Between Wounding and Tissue Repair. Diabetes, 52(2), 2143-2154.

Chereddy, K. K., Her, C., Comune, M., Moia, C., Lopes, A., Porporato, P. E., Vanacker, J., Lam, M. C., Steinstraesser, L., Sonveaux, P., Zhu, H., Ferreira, L. S., Vandermeulen, G. \& Préat, V. (2014). PLGA Nanoparticles Loaded with Host Defense Peptide LL37 Promote Wound Healing. Journal of Controlled Release, 8(16), 1-12.

Danhier, F., Ansorena, E., Silva, J. M., Coco, R., Le, B. A. \& Préat, V. (2012). PLGA-based Nanoparticles: An Overview of Biomedical Applications, Journal of Controlled Release, 161(2), 505-522.

Fessi, H., Puisieux, F., Devissaguet, J. P., Ammoury, N. \& Benita, S. (1999). Nanocapsule Formation by Interfacial Polymer Deposition Following Solvent Dis- placement. International Journal of Pharmaeutical, 55(1), 1-4.

Francis, G., Zohar, K., Harinder, P. S., Makkar \& Klaus, B. (2002). The Biological Action of Saponins in Animal Systems: a Review. The British of Journal, 88(6), 587-605.

Furman, B. L. (2015). Streptozotocin-induced Diabetic Models in Mice and Rats. Current Protocols in Pharmacology, 70(5), 1-20.

Gurtner, G. C. (2007). Wound Healing: Normal and Abnormal. Philadelphia: Grabb dan Smith's Plastic Surgey Sixth edition.

Hartanto, T. (2013). Pengaruh Antimikroba Ekstrak Kulit Manggis (Garcinia mangostana L.) terhadap Pertumbuhan Shigella dysenteriae secara in vitro. Semarang: Fakultas Kedokteran Universitas Islam Sultan Agung.

Keller, U., Kumin, A., Braun, S. \& Werner, S. (2006). Reactive Oxygen Species and their Detoxification in Healing Skin Wound. Journal of Investigative Dermatology Symposium Proceeding, 11(1), 106-111.

Khan, Z. I., Badrun, N., Abu, J., Shahnaz, R., Majeedul, H. C. \& Mohammed, R. (2010). An Evaluation of Antihyperglicemic and Antinociceptive Effects of Methanol Extract of Cassia fistula (Fabaceae) Leaves in Swiss Albino Mice. Advances in Natural and Applied Sciences, 4(3), 305-310.

Malini, D. M., Madihah., Joko, K., Fitri, K. \& Johan, I. (2017). Ethnobotanical Study of Medicinal Plants in Karangwangi, District of Cianjur, West Java. Biosaintifika, 9(2), 345-356.

Mathur, M. \& Govind, V. (2013). Role of Nanoparticles for Production of Smart Herbal Drug. Indian Journal of Natural 


\section{JURNAL BIDDJATI}

http://journal.uinsgd.ac.id/index.php/biodjati

Products and Resources, 4(4), 329-338. Napangala, A., Susianti \& Apriliana, E. (2012). Pengaruh Pemberian Getah Tanaman Jarak Pagar (Jatropha curcas L.) Secara Topikal terhadap Tingkat Kesembuhan Luka Iris pada Tikus Jantan Putih Galur Spargue Dawley. Medical Journal of Lampung University, 3(5), 26-35.

Nisa, M. V., Meilawaty, Z. \& Astuti, P. (2013). Efek Pemberian Ekstrak Daun Singkong (Manihot esculenta) terhadap Proses Penyembuhan Luka Gingiva Tikus (Rattus norvegicus). Thesis. Jember: Fakultas Kedokteran Gigi Universitas Jember.

Raffa, V., Vittorio, O., Riggio, C. \& Cuschieri, A. (2010). Progress in Nanotechnology for Healthcare. Minim Invasive Ther Allied Technology, 19(3), 127-35.

Rahmawati, I. (2014). Perbedaan Efek Perawatan Luka Menggunakan Gerusan Daun Petai Cina (Leucaena glauca Benth) dan Povidon Iodine 10\% dalam Mempercepat Penyembuhan Luka Bersih pada Marmut (Cavia porcellus), 1(2), 227-234.

Robert, G. F., Zgonis, T., Armstrong, D. G., Driver, V. R., Giurini, J. M., Kravitz, S. R., Landsman, A. S., Lavery, L. A., Moore, J. C., Schuberth, J. M., Wukich, D. K., Andersen, C. \& Vanore, J. V. (2006). Diabetic Foot Disorder a Clinical Practice Guideline. USA: American College of Foot and Ankle Surgeons.
Sahoo, S. K. \& Labhasetwar, V. (2003). Nanotech Approaches to Drug Delivery and Imaging. Drug Discov Today, 8(11), 1220.

Sari, F. P. \& Sari, S. M. (2011). Ekstraksi Zat Aktif Antimikroba dari Tanaman Yodium (Jatropha multifida Linn) sebagai Bahan Baku Alternatif Antibiotik alami. Thesis. Semarang: Fakultas Teknik Universitas Diponegoro.

Saroja, M., Santhi, R. \& Annapoorani, S. (2012). Wound Healing Activity of Flavonoid Fraction of Cynodon Dactylon in Swiss Albino Mice. International Research Journal of Pharmacy, 3(2), 23-31.

Sudayo, A. W., Setiyohadi, B., Alwi, I., Simadibrata, M. K. \& Setiati, S. (2009). Buku Ajar Ilmu Penyakit Dalam Edisi V Jilid III. Jakarta: Internal Publishing.

Wientarsih, I., Winarsih, W. \& Sutardi, I.N. (2012). Aktivitas Penyembuhan Luka oleh Gel Fraksi Etil Asetat Rimpang Kunyit pada Mencit Hiperglikemik. Jurnal Veteriner, 13(3), 251-256.

Winarsih, W., Wientarsih, I. \& Sutardi, I. N. (2012). Aktivitas Salep Ekstrak Rimpang Kunyit dalam Proses Penyembuhan Luka pada Mencit yang Diinduksi Diabetes. Jurnal Veteriner, 13(3), 242250.

Yanhendri \& Yenny, S. W. (2012). Berbagai Bentuk Sediaan Topikal dalam Dermatologi. Cermin Dunia Kedokteran, 39(6), 423-430. 